\title{
Renewable Diesel Production from Palm Fatty Acids Distillate (PFAD) via Deoxygenation Reactions
}

\author{
Brenda Fernanda Honorato de Oliveira ${ }^{1, *}$, Luiz Ferreira de França ${ }^{2}$, Nádia Cristina Fernandes Corrêa ${ }^{2}$, \\ Nielson Fernando da Paixão Ribeiro ${ }^{3}$ and Mauricio Velasquez $4, *$ (D) \\ 1 Programa de Pós-Graduação em Engenharia Química (PPGEQ), ITEC, Universidade Federal do Pará (UFPA), \\ Rua Augusto Correa 1, Belém 66075, Brazil \\ 2 Faculdade de Engenharia de Alimentos (FEA), Universidade Federal do Pará (UFPA), Belém 66075, Brazil; \\ 60franca@gmail.com (L.F.d.F.); ncfcorrea@gmail.com (N.C.F.C.) \\ 3 Faculty of Chemical Engineering (FEQ), ITEC, Universidade Federal do Pará (UFPA), Rua Augusto Correa 1, \\ Belém 66075, Brazil; nielson@ufpa.br \\ 4 Estado Sólido y Catálisis Ambiental (ESCA), Departamento de Química, Facultad de Ciencias, \\ Universidad Nacional de Colombia, Kra 30, Bogotá 111321, Colombia \\ * Correspondence: brendafho@ufpa.br (B.F.H.d.O.); lmvelasquezma@unal.edu.co (M.V.); \\ Tel.: +55-91-983484604 (B.F.H.d.O.); +57-1-3165000 (ext. 14422) (M.V.)
}

Citation: Honorato de Oliveira, B.F.; de França, L.F.; Fernandes Corrêa, N.C.; Ribeiro, N.F.d.P.; Velasquez, M. Renewable Diesel Production from Palm Fatty Acids Distillate (PFAD) via Deoxygenation Reactions. Catalysts 2021, 11, 1088. https:// doi.org/10.3390/catal11091088

Academic Editor: Maria A. Goula

Received: 14 July 2021

Accepted: 4 August 2021

Published: 9 September 2021

Publisher's Note: MDPI stays neutral with regard to jurisdictional claims in published maps and institutional affiliations.

Copyright: (C) 2021 by the authors Licensee MDPI, Basel, Switzerland. This article is an open access article distributed under the terms and conditions of the Creative Commons Attribution (CC BY) license (https:// creativecommons.org/licenses/by/ $4.0 /)$.

\begin{abstract}
The reactions to produce liquid biofuels from a palm fatty acid distillate (PFAD) under hydrogen absence were carried out using $10 \mathrm{wt} \% \mathrm{NiO} /$ zeolite $(\mathrm{Ni} / \mathrm{Zeo}), 10 \mathrm{wt} \% \mathrm{Co}_{3} \mathrm{O}_{4} /$ zeolite $(\mathrm{Co} / \mathrm{Zeo})$, and $10 \mathrm{wt} \%\left(\mathrm{NiO}+\mathrm{Co}_{3} \mathrm{O}_{4}\right) /$ zeolite $(\mathrm{NiCo} / \mathrm{Zeo})$ as catalysts. The zeolite was synthesized by a thermal and chemical treatment from natural clay, obtaining a zeolite A and sodalite mixture. Catalytic activity was evaluated as a function of reaction temperature $\left(250,300\right.$, and $\left.350{ }^{\circ} \mathrm{C}\right)$ during $0.5 \mathrm{~h}$ and using $5 \mathrm{wt} \%$ of catalyst. The reaction products were classified as organic liquid products (OLPs), gaseous products, and solid waste. The OLPs fractions were separated by fractional distillation, and the products were identified and quantified using gas chromatography coupled to a mass spectrometer detector (GC-MS). The results showed yields to OLPs above $50 \%$ for all catalysts and temperatures. However, the highest yield to OLPs of $67.9 \%$ was reached with a NiCoZeo catalyst at $300{ }^{\circ} \mathrm{C}$. In this reaction, a higher yield to hydrocarbons was obtained $(84.8 \%)$, indicating a cooperative effect between $\mathrm{Ni}$ and $\mathrm{Co}$ in the catalyst. Hydrocarbons such as heptadecane $\left(\mathrm{C}_{17} \mathrm{H}_{36}\right)$, pentadecane $\left(\mathrm{C}_{15} \mathrm{H}_{26}\right)$, and other alkanes-alkenes with lower carbon chains were the main products. Therefore, deoxygenation of PFAD using a low-cost Ni-Co catalyst was shown to be an economic and viable way to produce diesel-type biofuels.
\end{abstract}

Keywords: palm fatty acids distillate (PFAD); biofuel production; Ni-Co oxides; zeolite A; deoxygenation

\section{Introduction}

The current dependence on petroleum as a primary energy resource is associated with different environmental problems such as high emissions of gases ( $\mathrm{SO}, \mathrm{NOx}, \mathrm{CO}$, $\mathrm{CO}_{2}$, and $\mathrm{COVs}$ ) that are responsible for phenomena such as acid rain and climate change. Additionally, it is well known that the petroleum reserves are finite; therefore, the search for new efficient energy vectors obtained from renewable sources is a priority for actual government policies and private enterprises. In this sense, different technologies and renewable raw materials have been investigated for biofuel production [1,2].

Recently, the valorization of different agroindustrial wastes such as those obtained in the palm oil purification process has emerged as a good alternative for biofuel production due to several environmental and economic benefits [3,4].

The palm fatty acid distillate (PFAD) is a byproduct of the physical refining and deodorization of crude palm oil and is mainly composed of free fatty acids such as palmitic $\left(\mathrm{C}_{16}\right)$ and oleic $\left(\mathrm{C}_{18}\right)$. Therefore, valorization of this raw material has gained interest in the 
past few years since it does not compete with the food industry and has the potential to be transformed into diesel- or gasoline-type fuels through catalytic reactions such as cracking and deoxygenation [5-7].

In the biofuels industry, natural free fatty acids with 16-18 carbon atoms are used to produce renewable diesel (or green diesel) by removing the oxygen content and finally producing the respective hydrocarbons, in which the number of the carbon chain can be different according to the type of reaction that takes place [6,7]. Renewable diesel has some advantages over diesel obtained from petroleum since, being generated only from free fatty acids, it does not contain heteroatoms such as nitrogen and sulfur, which after combustion generate nitrogen oxides (NOx) and sulfur oxides (SOx) [8,9].

On the other hand, renewable diesel also presents some advantages over biodiesel due to its low oxygen content, which improves some properties of fuel such as high oxidation stability and higher cetane number [10-12]. The reaction pathways through oxygen that are removed from free fatty acids are known as hydrodeoxygenation (HDO) and deoxygenation (DO). The latter can occur as a decarbonylation $(-\mathrm{CO})$ or decarboxylation $\left(-\mathrm{CO}_{2}\right)$ process $[6,13,14]$. Nevertheless, parallel and consecutive reactions such as thermal and catalytic cracking could take place depending on the catalyst nature and reaction conditions $[4,15,16]$.

The HDO is a hydrogenolysis reaction in which the oxygen atoms are removed in the presence of hydrogen to produce water and complete carbon chains [2,17]. In contrast to HDO, in the deoxygenation reactions, the oxygen removal proceeds by cracking/deoxygenation steps with $\mathrm{CO}$ and $\mathrm{CO}_{2}$ liberation without hydrogen consumption $[3,11,13]$.

Thus, although the HDO process generates hydrocarbons with better quality than DO due to a higher number of carbon atoms, the high hydrogen consumption in HDO reactions implies a disadvantage from an economic point of view. In this sense, deoxygenation reactions in absence of hydrogen represent an economic alternative to produce biofuels with similar properties as those obtained from petroleum $[6,13,18]$.

The metal oxides of transition metals such as $\mathrm{Ni}, \mathrm{Co}, \mathrm{Mo}, \mathrm{W}, \mathrm{Zn}, \mathrm{Fe}$, and $\mathrm{Cu}$ have been evaluated as catalysts in DO reactions $[10,13,14,16,17]$. Some of them have been supported in zeolites with acid properties, influencing important reactions such as cracking and/or isomerization of the carbon chains [19].

The catalytic properties of these metal oxides come from the adsorption of reagents on unsaturated metal sites and/or oxygen atoms, followed by the addition and/or elimination of oxygen that promotes the breakdown of fatty acids [20]. Thus, they are effectively decreasing the levels of oxygenated products in the final biofuel, improving its quality [21].

On the other hand, recent studies report that $\mathrm{Ni}$ - and $\mathrm{Co}$-based catalysts have a catalytic performance similar to those synthesized with noble metals ( $\mathrm{Pd}$ and $\mathrm{Pt}$ ), making them a promising and lower-cost alternative technologically $[1,22,23]$. In this way, supported metal catalysts have gained importance since they manage to couple high catalytic activity, directing selectivity to desired products such as gasoline, diesel, or chemical intermediates $[16,24,25]$.

Nowadays, few studies over the valorization of palm fatty acid distillate (PFAD) as a substrate to produce biofuels have been published. Therefore, this is a field that needs more exploration about the catalysts' design, reaction conditions, and impurities effect, among others. In this regard, this work aims to contribute to the preparation, characterization, and evaluation of low-cost catalysts for the conversion of PFAD and its selectivity to liquid hydrocarbons.

\section{Results}

\subsection{Characterization of Catalysts}

In the synthesis of zeolite, the first step was the thermal treatment of the waste material (obtained from kaolin production) at $600{ }^{\circ} \mathrm{C}$ for $2 \mathrm{~h}$. Through this thermal treatment was obtained the metakaolin, which is an amorphous material generated because of deshydroxylation reaction by the cleavage of hydrogen bonds between the alumina octahedral layers and silica tetrahedral layers. Therefore, to observe changes in the crystallinity of the 
starting material, XRD analysis was carried out, and the spectra can be observed in Figure 1. The XRD pattern of natural material showed diffraction peaks at $12.64^{\circ}$ and $25.05^{\circ} 2 \theta$, which are characteristics of kaolinite (ICOD 01-078-2110). The presence of quartz $\left(26.47^{\circ} 2 \theta\right.$, COD 96-200-5023) and $\mathrm{TiO}_{2}$ (37.71 $2 \theta$ anatase, COD 96-720-6076) in low intensity were also observed. The XRD pattern after calcination showed only the quartz signal, indicating the destruction of the crystalline structure [26,27]. After zeolite synthesis and calcination, diffraction peaks attributed to zeolite A (ICOD 01-089-5421) and sodalite (COD 96-900-3327) were observed [27-29].

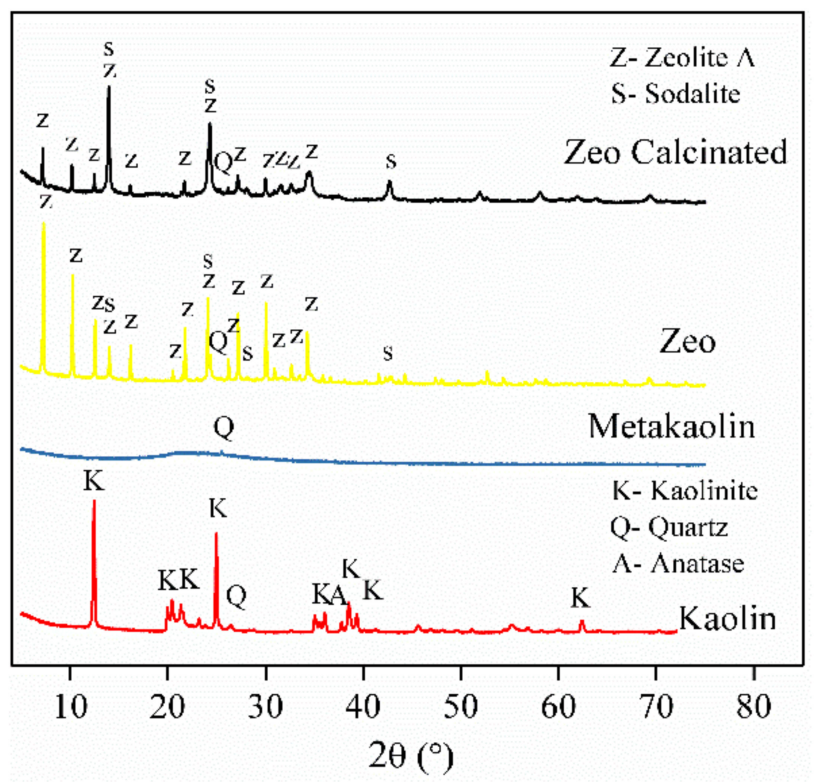

Figure 1. XRD patterns of the zeolite synthesis process.

X-ray diffraction patterns of catalysts are shown in Figure 2. For the NiZeo catalyst, diffraction peaks at $37.48^{\circ}, 43.54^{\circ}$, and $62.84^{\circ} 2 \theta$ were attributed to the cubic structure of $\mathrm{NiO}$ (ICOD 01-073-1523) [3,30]. In this spectrum it was also observed that the incorporation of nickel did not seem to destroy the structure of zeolitic material [31].

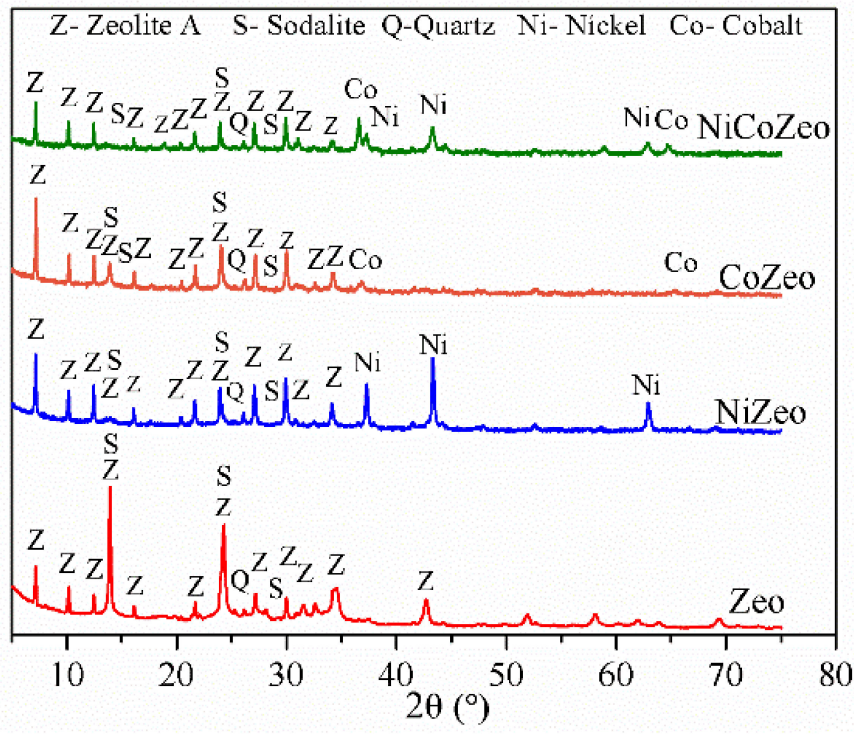

Figure 2. XDR of synthesized catalysts.

On the other hand, the spectrum of CoZeo showed low intensity peaks characteristic of cobalt oxides. The peaks at $36.87^{\circ}$ and $65.51^{\circ} 2 \theta$ were attributed to the cubic structure 
of $\mathrm{Co}_{3} \mathrm{O}_{4}$ (ICOD 00-001-1152) [10,24]. However, the low intensities of these could be associated with the formation of the amorphous phase of cobalt oxide, but also with a high dispersion of cobalt oxide particles over the zeolitic support. In the bimetallic catalyst NiCoZeo, the two phases of oxides $\left(\mathrm{NiO}\right.$ and $\left.\mathrm{Co}_{3} \mathrm{O}_{4}\right)$ were observed. The latter had higher intensity than the former of the CoZeo catalyst. However, no common crystalline structure of Ni-Co was observed.

The nitrogen adsorption-desorption isotherms of support and catalysts are shown in Figure 3. Typical type IVa isotherms were observed, which are associated with mesoporous materials. In these isotherms, a type $\mathrm{H} 3$ hysteresis loop was observed, suggesting the presence of mesopores wider than $4 \mathrm{~nm}$. However, capillary condensation around the high $\mathrm{p} / \mathrm{p}^{\circ}$ range also suggested the presence of macropores that were not filled. Applying the BET model, the specific surface area calculated for the zeolite was $3 \mathrm{~m} 2 / \mathrm{g}$, which is around the error value of the instrument, whereas for all catalysts these values were around $14 \mathrm{~m} 2 / \mathrm{g}$, as can be seen in Table 1 . The low value for the zeolite indicates a low presence of mesopores and, according to the isotherm, its hysteresis can be associated only with macropores. This suggests that the incorporation of metal oxides of $\mathrm{Ni}$ and/or Co induced a certain mesoporosity on the surface $[32,33]$.
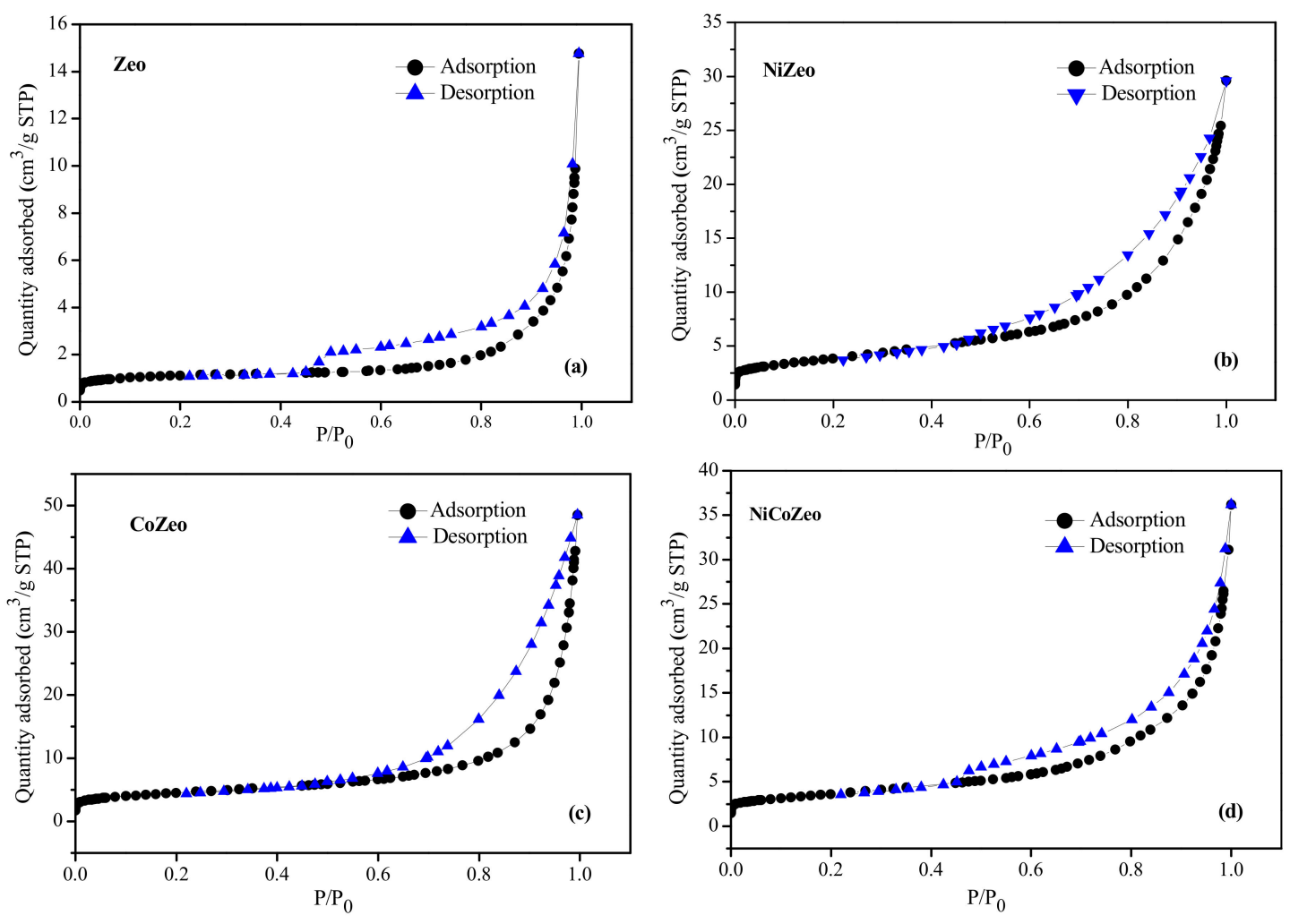

Figure 3. $\mathrm{N}_{2}$ adsorption-desorption isotherms. (a) Zeolite, (b) NiZeo, (c) CoZeo and (d) NiCoZeo.

Table 1. Textural properties of zeolite and catalysts.

\begin{tabular}{|c|c|c|c|c|}
\hline Catalyst & $\begin{array}{c}\mathrm{S}_{\mathrm{BET}} \\
\left(\mathrm{m}^{2} / \mathrm{g}\right)\end{array}$ & $\begin{array}{c}D_{\text {pore size }}{ }^{a} \\
(\mathrm{~nm})\end{array}$ & Pore Volume ${ }^{b}\left(\mathrm{~cm}^{3} / \mathrm{g}\right)$ & Metal Oxide Crystallite Size $(\mathrm{nm})^{c}$ \\
\hline $\mathrm{ZeO}$ & 3 & 26.8 & 0.02 & 73 \\
\hline NiZeo & 13.4 & 13.7 & 0.05 & 43.00 \\
\hline CoZeo & 14.8 & 20.2 & 0.07 & 13.83 \\
\hline $\mathrm{NiCoZeO}$ & 12.4 & 18.0 & 0.06 & $23.71(\mathrm{Ni}) / 21.56(\mathrm{Co})$ \\
\hline
\end{tabular}

a Average pore size obtained by BJH method on the desorption branch. ${ }^{\mathrm{b}}$ Average pore volume obtained by BJH method on the desorption branch. ${ }^{c}$ Calculated by using Scherrer equation based on XRD diffraction pattern. 
Morphological properties of metakaolin and synthesized zeolite can be observed in Figure 4. For metakaolin (Figure 4a), the total breakdown of the kaolin structure was evidenced, remaining an amorphous and agglomerated structure in lamellar shape [26]. For the zeolitic material before and after calcination (Figure $4 \mathrm{~b}$ ), the presence of two distinct structures was observed. The first one had rounded shapes like woolen balls, which is characteristic of polycrystals of sodalite, and the second one had the form of crystalline cubes, which is typical of the zeolite A morphology $[29,34,35]$. Therefore, these results are in concordance with the analysis made by XRD.

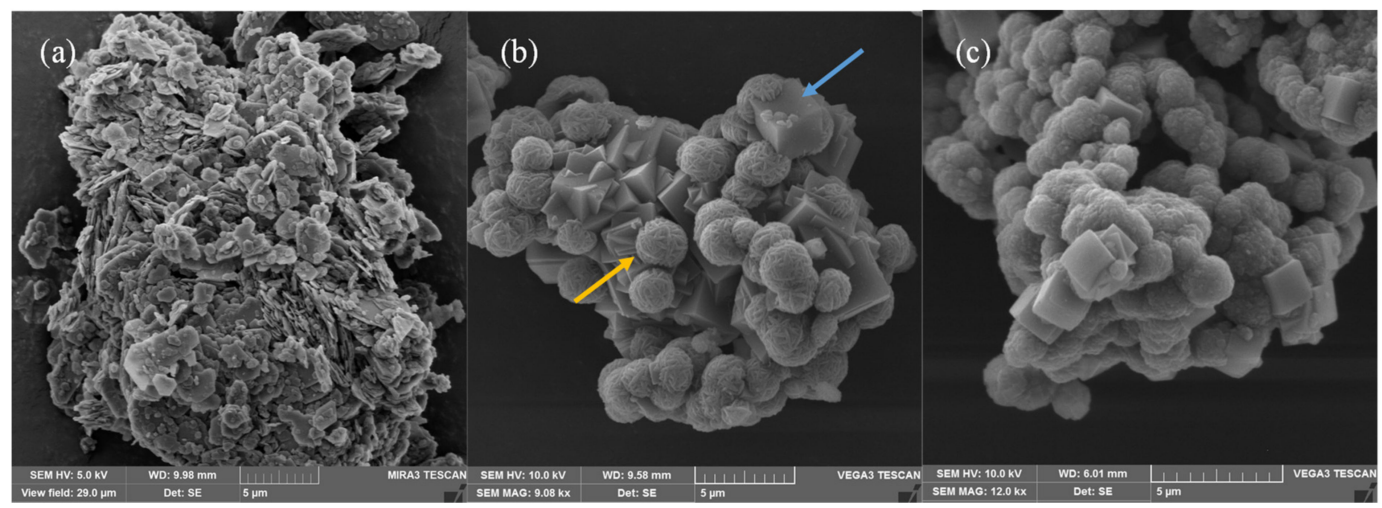

Figure 4. SEM images of zeolite synthesis process. (a) metakaolin, (b) zeolite after synthesis and (c) calcined zeolite.

Micrographs for synthesized catalysts are shown in Figure 5. There can be seen a loss of the characteristic morphologies of the zeolite A and sodalite, suggesting that this material is being covered by metal oxide, as can be seen in the EDX elemental mapping. For the NiZeo catalyst (Figure 5a), the presence of small particles over the surface can be seen, suggesting the presence of NiO. Nevertheless, for the CoZeo catalyst (Figure 5b), the morphology was shown to be different, since the support appears to be surrounded by a thin layer of interconnected filaments, possibly constituted by cobalt oxide. Finally, in the bimetallic catalyst (NiCoZeo) image, the surface of the support also appears to be surrounded by a thin layer of particles. However, for this catalyst, a more homogeneous distribution of the particles in comparison with the NiZeo catalyst can be observed.

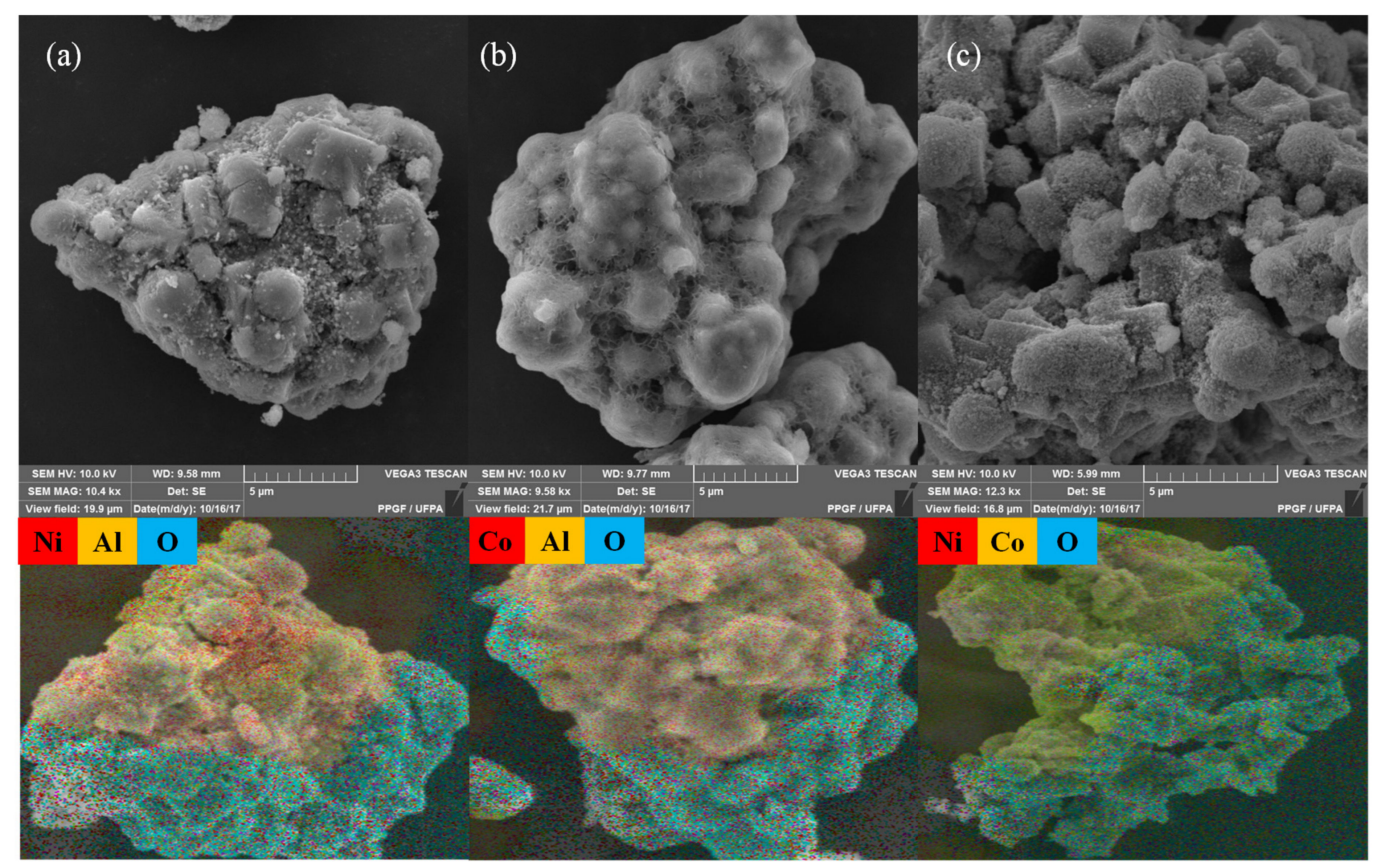

Figure 5. SEM images and EDX elemental mapping of the catalysts. (a) NiZeo, (b) CoZeo and (c) NiCoZeo. 
Figure 6 shows the DRIFT-NH3 spectra of zeolitic material as a function of NH3 desorption temperature. According to literature reports, the band observed around $1660 \mathrm{~cm}^{-1}$ is attributed to vibrations of the $\mathrm{N}-\mathrm{H}$ bonds in the $\mathrm{NH} 3$ molecule that are coordinatively adsorbed on Lewis acid sites associated with aluminum atoms on the surface. The band at $1430 \mathrm{~cm}^{-1}$ is related to the asymmetric flexion of the $\mathrm{N}-\mathrm{H}$ bond in the ammonium ion chemisorbed on Brønsted acid sites, indicating the acidic character of the support $[30,36,37]$.

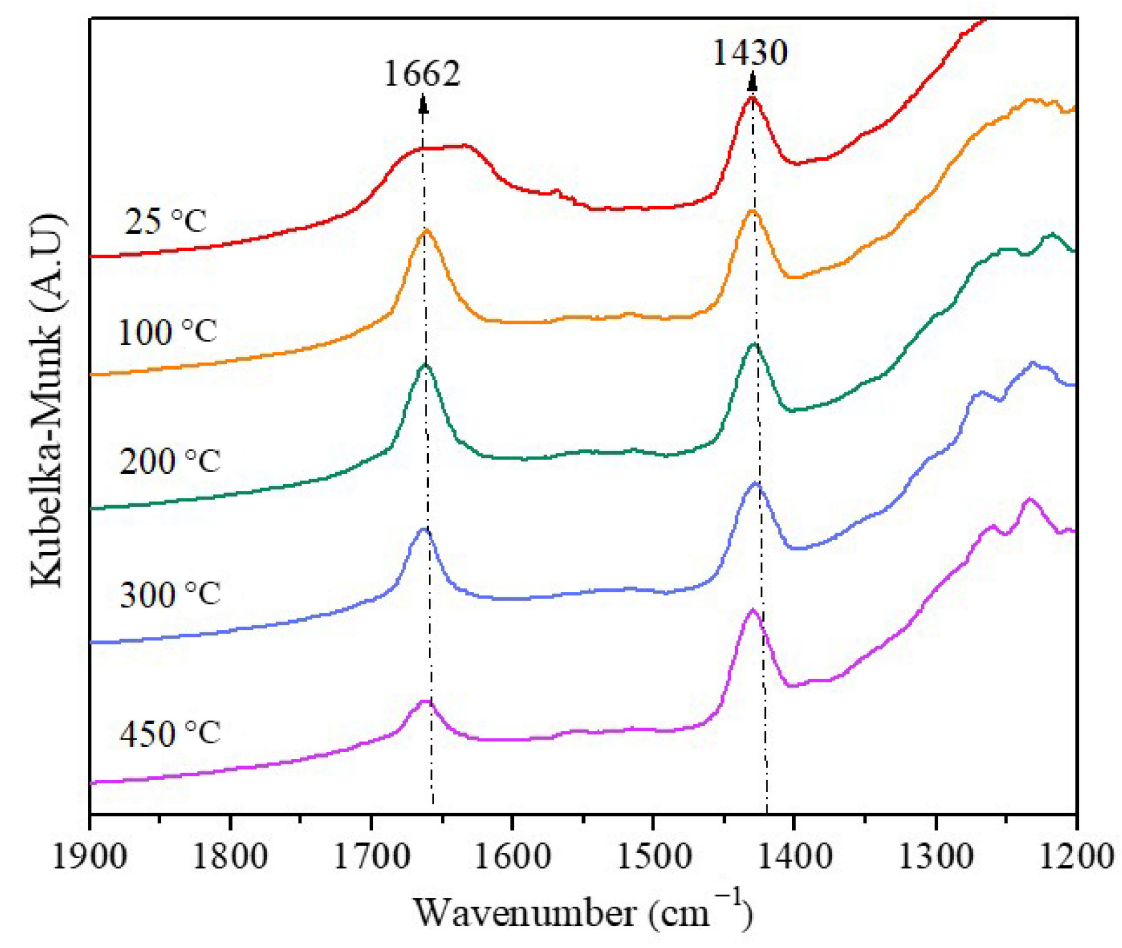

Figure 6. DRIFT spectra of $\mathrm{NH}_{3}$ adsorbed on Zeolite.

Regarding the effect of temperature, the strength of these acid sites can be analyzed following the change in the area at the different desorption temperatures (Figure 7). For Brønsted acid sites, between room temperature and $100^{\circ} \mathrm{C}$, there was a slight decrease in the area, suggesting the presence of some acid sites of low strength. However, for high temperatures, the areas were relatively constant, indicating the presence of high strength Brønsted acid sites. For Lewis acid sites, between room temperature and $100{ }^{\circ} \mathrm{C}$, the change in the area suggested the presence of low strength acid sites. Even this change in the area could be attributed to physisorbed ammonia. Between $100{ }^{\circ} \mathrm{C}$ and $200{ }^{\circ} \mathrm{C}$, the areas were constant, which can be associated with medium strength acid sites, and after $200{ }^{\circ} \mathrm{C}$ the areas were lower, indicating a low number of acid sites of high strength. 


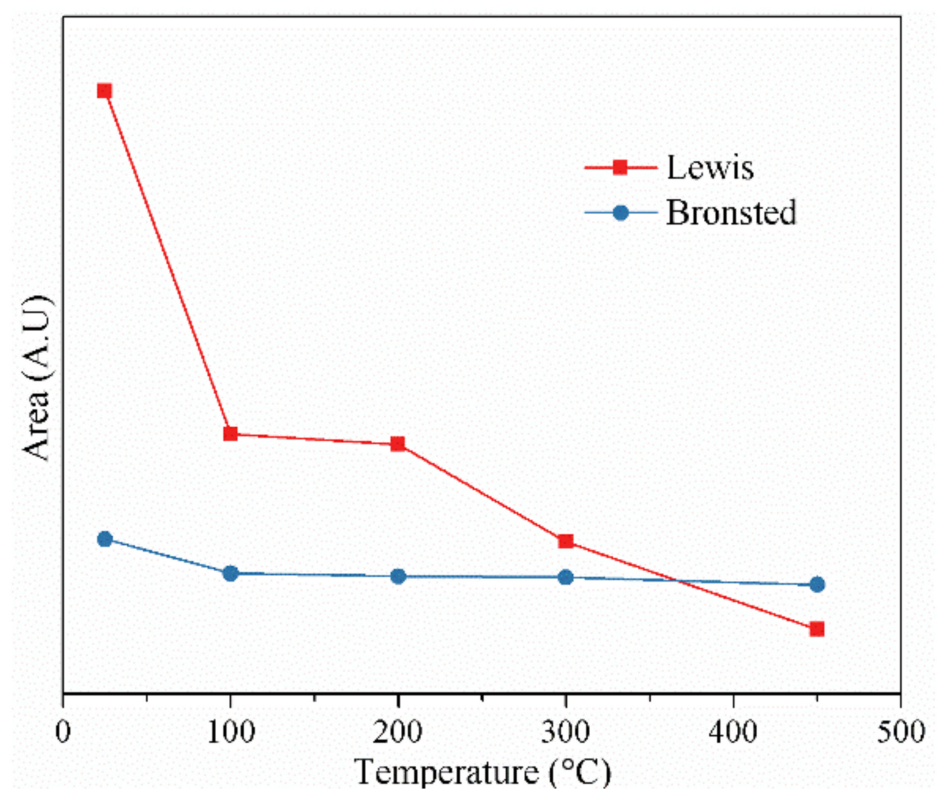

Figure 7. Normalized area of $\mathrm{NH}_{3}$ adsorbed on Lewis and Brønsted acid sites of the catalyst as a function of temperature.

\subsection{PFAD Composition}

The composition of palm fatty acid distillate is shown in Table 2. According to GC results, approximately $95 \%$ were formed by free fatty acids with a predominance of palmitic acid (16:0) and oleic acid (18:1). Other C18 free fatty acids such as stearic acid (18:0) and linoleic acid (18:2) were found. This suggests that these free fatty acids can be transformed to hydrocarbons of $\mathrm{C}_{15}$, like pentadecane $\left(\mathrm{C}_{15} \mathrm{H}_{32}\right), \mathrm{C}_{17}$, such as heptadecane $\left(\mathrm{C}_{17} \mathrm{H}_{36}\right)$, and /or its respective alkenes through deoxygenation reactions. Additionally, the presence of Brønsted acid sites in the support could also induce cracking reactions that form hydrocarbons of lower carbon chains $[1,11,38]$.

Table 2. Physicochemical properties and chemical composition of the PFAD.

\begin{tabular}{cc}
\hline \multicolumn{2}{c}{ Properties } \\
\hline Acid Value $\left(\mathrm{mg} \mathrm{KOH} \mathrm{g}^{-1}\right)$ & 144.7 \\
Viscosity at $40^{\circ} \mathrm{C}(\mathrm{cSt})$ & 20.8 \\
Calorific Value $(\mathrm{MJ} / \mathrm{kg})$ & 41.5 \\
\hline \multicolumn{2}{c}{ Fatty Acid Composition of Oil (\%) } \\
\hline Lauric acid (C12:0) & 1.21 \\
Myristic acid (C14:0) & 1.24 \\
Palmitic acid (C16:0) & 43.09 \\
Stearic acid (C18:0) & 7.86 \\
Oleic acid (C18:1) & 37.54 \\
linoleic acid (C18:2) & 4.715 \\
\hline
\end{tabular}

\subsection{Catalytic Activity}

Experiments of thermal and catalytic conversion of PFAD were carried out with different catalysts and by varying the reaction temperature. The results of OLPs, gas production, and solid waste can be observed in Figure 8. All thermal reactions (without catalyst) showed OLPs yields between $60 \%$ and $68 \%$, indicating that, only with an increase in the temperature, thermodynamics leads to conversion of PFAD. However, although some works in the literature report similar results, the quality of the products obtained is undesirable because the high number of oxygenated products increases the acidity of 
biofuel. In addition, the distribution in the fractional distillation is often in the range of heavy products such as coke and lubricants $[16,39,40]$.

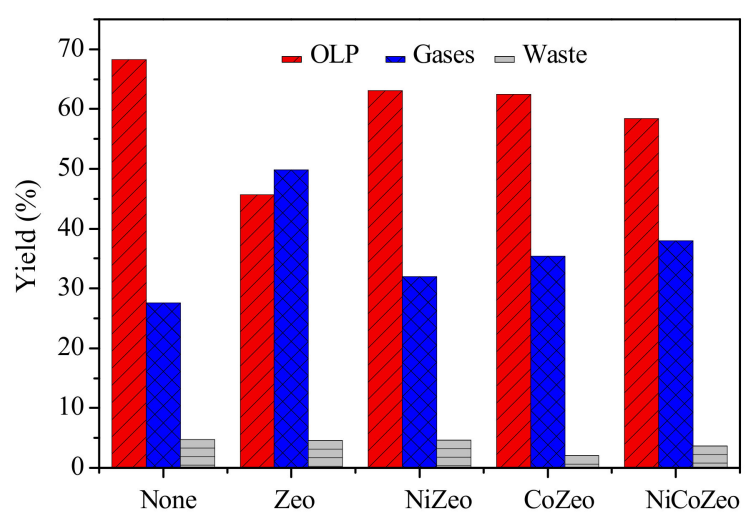

(a)

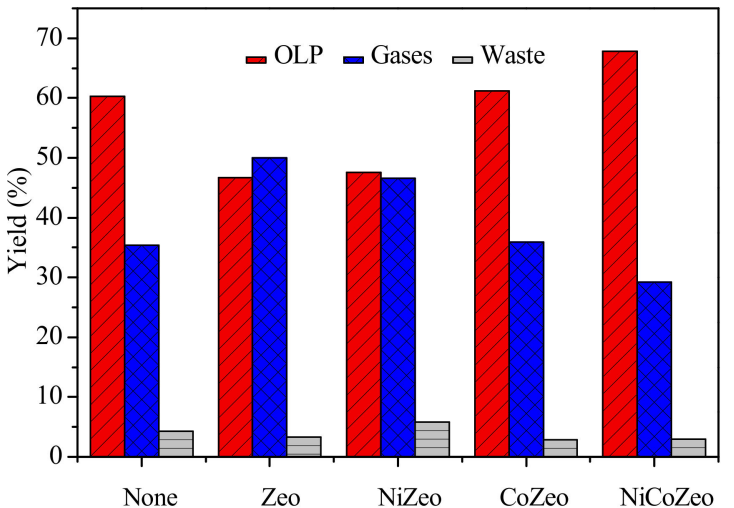

(b)

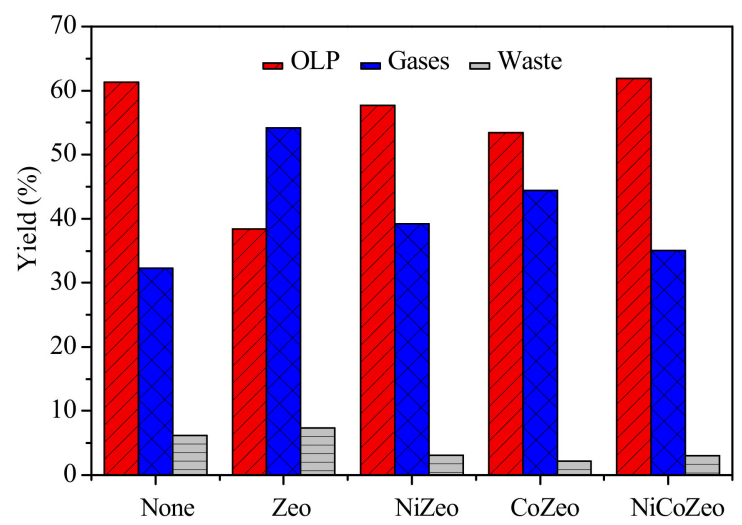

(c)

Figure 8. Yields to liquid, gaseous and solid products in DO reactions at different temperatures. (a) $250{ }^{\circ} \mathrm{C},(\mathbf{b}) 300{ }^{\circ} \mathrm{C}$ and (c) $350{ }^{\circ} \mathrm{C}$.

On the other hand, the results for zeolite support showed OLPs yields lower than $45 \%$, indicating the influence of the acidity in the generation of gaseous products. In the work of Li et al., 2016 [41], they obtained similar results with yields to gaseous products between $45 \%$ and $60 \%$ in the catalytic cracking of residual cooking oil with different types of zeolites (HZSM-5, NaY, USY e MCM-41) [41].

For all catalysts, the OLPs yields were higher than zeolite support at different temperatures (between $47 \%$ and $67 \%$ ). These results suggest that the incorporation of metal oxides on the surface of zeolite decreases the number of acid sites on the surface, and therefore the cracking reactions to gas products are given in a lower proportion. The catalysts with higher reactivity to OLPs fractions were NiZeo at $250{ }^{\circ} \mathrm{C}(63.1 \%)$, CoZeo at $250{ }^{\circ} \mathrm{C}(62.5 \%)$, and $\mathrm{NiCoZeo}$ at $300{ }^{\circ} \mathrm{C}(67.9 \%)$. Nevertheless, similar results were found at $350{ }^{\circ} \mathrm{C}$, indicating that there was not a significant effect of temperature related to OPL yields. Concerning solid waste, the yield for all reactions was lower than $7 \%$, and it was composed mainly of the free fatty acids unconverted.

\subsection{Analysis of Products}

Figure 9a shows the hydrocarbons yield calculated by GC-MS. For thermal reaction, significant percentages of hydrocarbons were obtained $\left(76 \%\right.$ at $\left.300{ }^{\circ} \mathrm{C}\right)$, showing that temperature is sufficient to generate DO reactions. However, according to Figure $9 \mathrm{~b}, \mathrm{a}$ selectivity of $46 \%$ to $C_{11}$ and $C_{14}$ and of $8 \%$ to $C_{8}$ and $C_{10}$ was obtained, indicating that thermal effects promote $\mathrm{DO}$ reactions followed by cracking reactions. Similar results were 
obtained for zeolite. However, a higher selectivity to light hydrocarbons $\left(C_{8}-C_{10}\right)$ was obtained compared to the thermal reaction. This is due to acid sites in the zeolite that induce the cleavage of $\mathrm{C}-\mathrm{C}$ bonds.

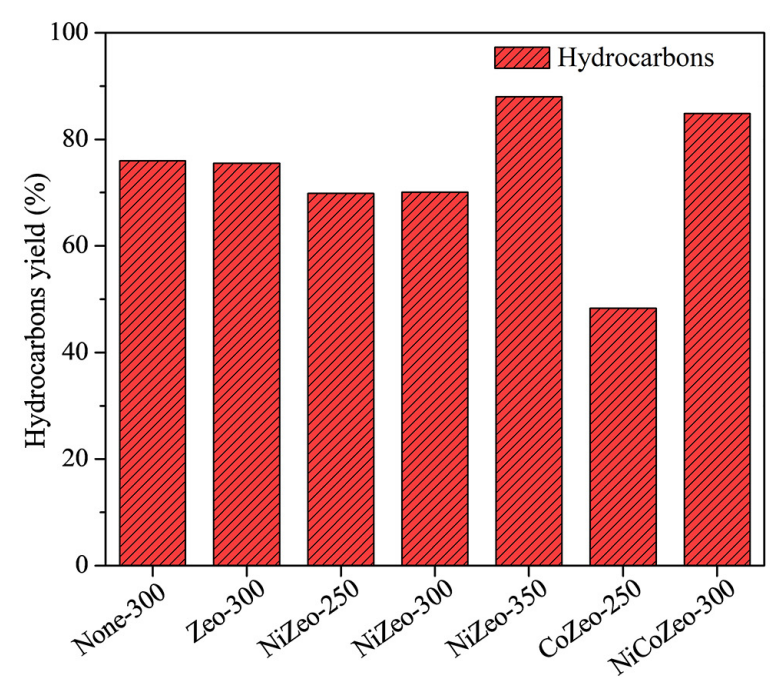

(a)

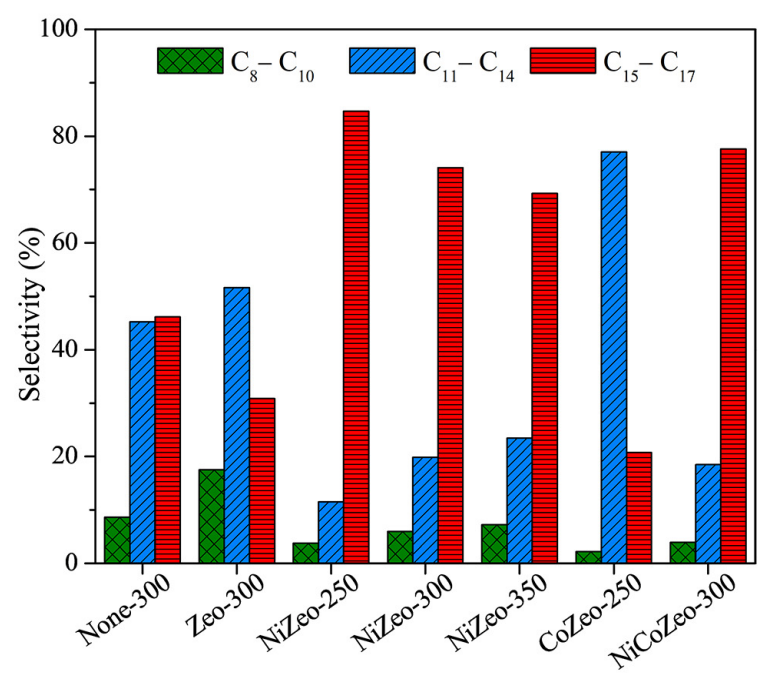

(b)

Figure 9. Catalytic activity and selectivity in DO reactions of PFAD. (a) hydrocarbons yield and (b) selectivity.

For the catalysts at different temperatures, the yield to hydrocarbons was higher than $70 \%$, except for the CoZeo, which showed the lower activity in DO reactions. Oxygenated compounds such as nonanol, n-decanoic acid, n-hexanoic acid, and free fatty acids unconverted, among others, were identified. The high catalytic activities in DO reactions were obtained for NiZeo at $350{ }^{\circ} \mathrm{C}(88.6 \%)$ and NiCoZeo at $300{ }^{\circ} \mathrm{C}(84.8 \%)$. However, although these yields were similar to those obtained with the zeolite and thermal reactions, the main differences were in the selectivity of products. For instance, for NiZeo at $350{ }^{\circ} \mathrm{C}$ and NiCoZeo at $300{ }^{\circ} \mathrm{C}$, the selectivity to $\mathrm{C}_{15}-\mathrm{C}_{17}$ hydrocarbons reached $68.7 \%$ and $78.2 \%$ respectively. Therefore, these results suggest that the presence of metal oxides in the catalyst increased the kinetic of deoxygenation reactions and limited the kinetic of cracking reaction, at least during the $0.5 \mathrm{~h}$ of reaction.

In the work of Peng et al., 2012 [42], the authors evaluated the deoxygenation reaction of stearic acid using a Ni-based catalyst supported over different $\mathrm{Si} / \mathrm{Al}$ ratio zeolites (HZSM-5 and HBeta) to evaluate the effect of the acidity of support. They reported that high acidity on the support (HZSM-5) conduced to high conversion of stearic acid, but severe cracking of the products was obtained (selectivity of $43 \%$ to $\mathrm{C}_{17}-\mathrm{C}_{18}$ alkanes). On the other hand, for lower acidity support (HBeta), the cracking effect was suppressed, and the selectivity of $\mathrm{C}_{17}-\mathrm{C}_{18}$ alkanes increased to $93 \%$.

Regarding the temperature effect, for the NiZeo catalyst at $350{ }^{\circ} \mathrm{C}$, the yield to hydrocarbons was $88.6 \%$. However, the selectivity of $C_{15}-C_{17}$ hydrocarbons (68.7\%) was lower than those obtained at $300{ }^{\circ} \mathrm{C}(74 \%$, with a yield to hydrocarbons of $70.3 \%)$ and $250{ }^{\circ} \mathrm{C}$ ( $87 \%$, with a yield to hydrocarbons of $69.8 \%$ ), indicating that high temperature increases the proportion of hydrocarbons but also the formation of cracked products.

For the bimetallic catalyst at $300{ }^{\circ} \mathrm{C}$, the yield of hydrocarbons was higher $(84.8 \%)$ than NiZeo at the same temperature $(70.3 \%)$, indicating a cooperative effect between nickel and cobalt in DO reactions. Additionally, it can be also observed that the presence of cobalt in the bimetallic catalyst does not affect the selectivity to $C_{15}-C_{17}$ hydrocarbons. Nevertheless, an unexpected result was obtained for the CoZeo catalyst since the conversion to hydrocarbons was lower than $45 \%$ and the selectivity was significantly oriented to cracked products $(75 \%$ to $\mathrm{C}_{11}-\mathrm{C}_{14}$ hydrocarbons). Similar results were reported in the work of Choo et al., 2020. The authors evaluated the effect of transition metal oxides as $\mathrm{Ni}$ and Co supported on 
zeolite $\mathrm{Y}$ (as monometallic catalysts) in the DO reaction of triolein as a model molecule at $380{ }^{\circ} \mathrm{C}$ for $2 \mathrm{~h}$. They showed that the Ni-Y was the most active catalyst with selectivity to hydrocarbons of $84.28 \%$ and for Co-Y catalysts around $78 \%$. Although both catalysts showed the high selectivity to hydrocarbons in the diesel range, the Co-Y had a higher amount of cracked products than Ni-Y. Therefore, this work concluded that a balance between Lewis and Brønsted acid sites in the zeolite added to the Ni ability to promote the deoxygenation reactions and suppress cracking reactions. In another recent work [22], the effect of cobalt in the bimetallic Ni-Co catalyst for hydrotreatment of fatty acid methyl esters was studied. These results showed that bimetallic catalysts provide higher deoxygenation yields than those monometallic catalysts at similar reaction temperatures $\left(300\right.$ and $\left.330{ }^{\circ} \mathrm{C}\right)$. The authors attributed the most of the activity of the bimetallic catalyst to the presence of cobalt active sites on the surface, which have a strong interaction with $\mathrm{CO}_{2}$ generated in the decarboxylation reaction. Thus, the synergy between $\mathrm{Co}$ and $\mathrm{Ni}$ atoms on the surface enhances the deoxygenation reactions to produce hydrocarbons.

\subsection{Reaction Pathways for Free Fatty Acid Deoxygenation}

Reaction pathways for converting free fatty acids to hydrocarbons under hydrogenfree conditions have been discussed by several authors [11,22,43,44]. Based on Table 2, PFAD is composed mainly of $\mathrm{C}_{16}$ and $\mathrm{C}_{18}$ free fatty acids which can be transformed to $\mathrm{C}_{15}$ and $\mathrm{C}_{17}$ through decarbonylation and/or decarboxylation reactions. According to this, a scheme of possible reaction routes is shown in Figure 10. For palmitic acid, the hydrocarbon generated by the decarbonylation reaction is pentadecene $\left(\mathrm{C}_{15} \mathrm{H}_{30}\right)$, and the other byproducts are $\mathrm{CO}$ and water (Figure 10 (a)). Thus, for the decarboxylation reaction, the hydrocarbon generated is pentadecane, and the by-product is $\mathrm{CO}_{2}$ (Figure $10(\mathrm{~b})$ ).

Palm fatty acid distillate (PFAD)

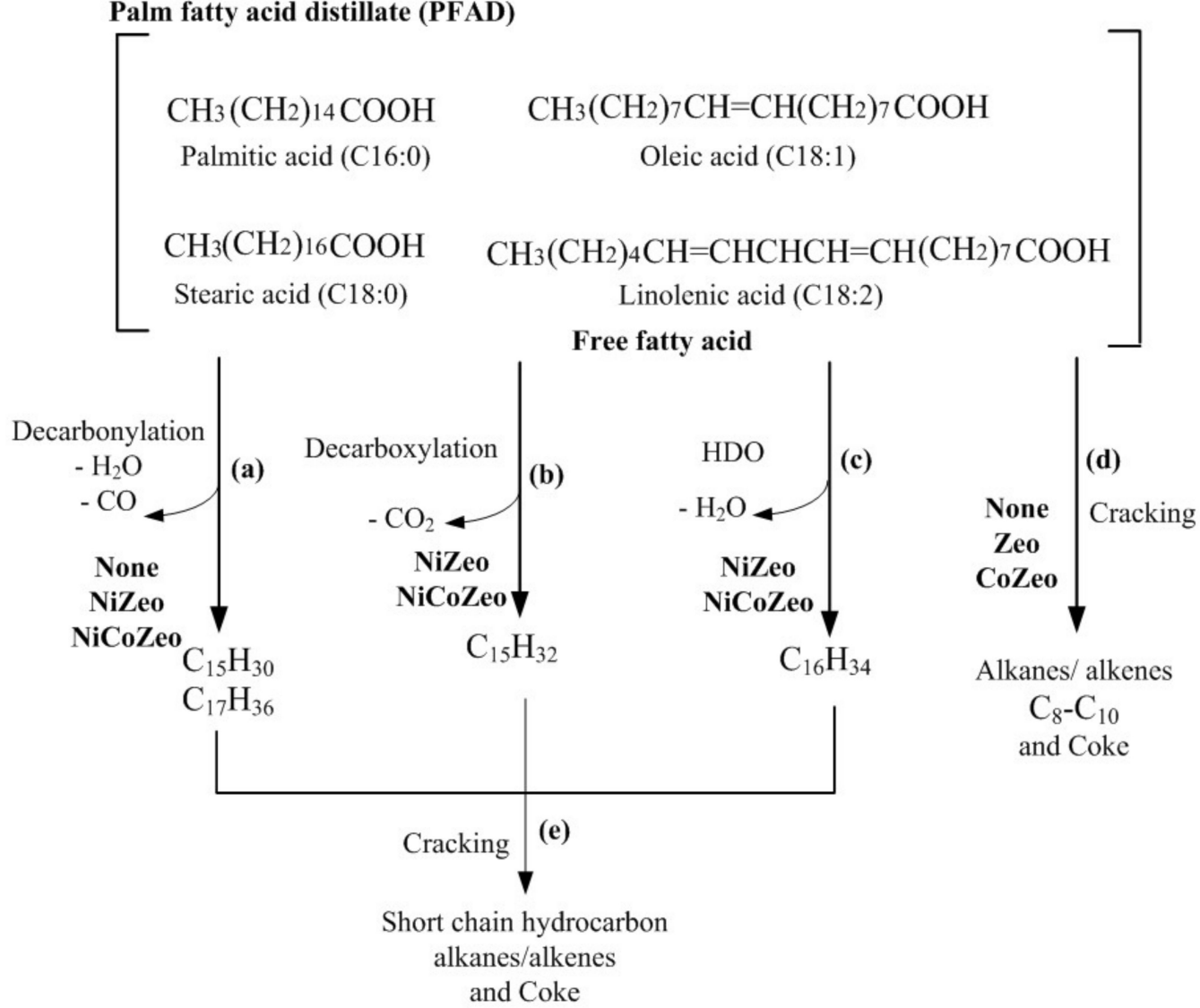

Figure 10. Deoxygenation reaction pathways of PFAD. 
On the other hand, for the different $C_{18}$ free fatty acids, the products formed could be different heptadecenes as byproducts of decarbonylation reactions, and heptadecane as a byproduct of the decarboxylation of stearic acid. However, other possible reactions that can generate molecular hydrogen, such as reverse water gas shift, can occur, which can generate hydrogenation reactions (alkenes to alkanes). Even HDO reactions could occur, which produces low fractions of hexadecanes and octadecanes (Figure 10 (c)). [45]. Additionally, coke formation is another reaction that must be considered, especially when an acid zeolite is used as a catalyst or support (Figure 10 (d) and (e)). After the reaction, recycled catalysts were evaluated by thermal analysis under inert and oxidative atmosphere, as can be observed in Table 3. In the analysis, the catalyst was heated under a nitrogen atmosphere $\left(30-280{ }^{\circ} \mathrm{C}\right)$, where the weight loss was related to physisorbed water and products. After that, the gas flux was changed to air, and the sample was heated between $280{ }^{\circ} \mathrm{C}$ and $550{ }^{\circ} \mathrm{C}$, where the weight loss was related to the oxidation of coke.

Table 3. Thermal analysis of recycled catalyst.

\begin{tabular}{|c|c|c|}
\hline Catalyst & $\begin{array}{l}\text { Water + Adsorbed Products (\%) } \\
\quad\left(30-280^{\circ} \mathrm{C} \text {, Nitrogen) }\right.\end{array}$ & $\begin{array}{c}\text { Coke }(\%) \\
\left(280-550{ }^{\circ} \mathrm{C}, \mathrm{Air}\right)\end{array}$ \\
\hline $\mathrm{NiCoZeo} 300^{\circ} \mathrm{C}$ & 51.02 & 21.80 \\
\hline CoZeo $250^{\circ} \mathrm{C}$ & 23.50 & 20.52 \\
\hline NiZeo $350^{\circ} \mathrm{C}$ & 20.38 & 23.11 \\
\hline NiZeo $300{ }^{\circ} \mathrm{C}$ & 37.82 & 10.30 \\
\hline NiZeo $250^{\circ} \mathrm{C}$ & 45.57 & 11.16 \\
\hline Zeo $300{ }^{\circ} \mathrm{C}$ & 27.95 & 14.56 \\
\hline
\end{tabular}

These results show a high production of coke for CoZeo at $250{ }^{\circ} \mathrm{C}$, while for the NiZeo at the same temperature, the coke formation was half, indicating the effect of the cobalt oxide in the $\mathrm{C}-\mathrm{C}$ cleavage. However, for the best catalyst, $\mathrm{NiCoZeo}$ at $300{ }^{\circ} \mathrm{C}$, the formation of coke was also important, suggesting that catalyst could be deactivated during long reaction times. Finally, it is well known that coke formation is a contribution to the acidity of the zeolite, as can be observed in Table 3, and the ability of the metals to cleavage the C-C bonds.

\section{Materials and Methods}

The palm fatty acid distillate (PFAD) used in this work was supplied by Agropalma S/A Company (Tailândia, Brazil). For zeolite synthesis, natural kaolin waste from the tailings pond of an industrial facility in the Amazon region was obtained. Nickel nitrate $\left(\mathrm{Ni}\left(\mathrm{NO}_{3}\right)_{2.3} \mathrm{H}_{2} \mathrm{O}(97 \%)\right.$ (Vetec, São Paulo, Brazil) and cobalt nitrate $\left(\mathrm{Co}\left(\mathrm{NO}_{3}\right)_{2} \cdot \mathrm{H}_{2} \mathrm{O}(97 \%)\right.$ (Dinâmica, São Paulo, Brazil) were used as precursors of oxides.

\subsection{Catalysts Preparation}

Zeolite was synthesized from a waste material obtained from kaolin production, according to the methodology reported in previous works [46,47].

Oxides $\left(\mathrm{NiO}, \mathrm{Co}_{3} \mathrm{O}_{4}\right.$, and $\left.\mathrm{NiO} / \mathrm{Co}_{3} \mathrm{O}_{4}\right)$ were prepared under nominal content of $10 \mathrm{wt} \% \mathrm{MeO} /$ zeolite using the wet impregnation method. Aqueous solutions of metallic nitrates were mixed with respective mass of zeolite during $4 \mathrm{~h}$ at room temperature. Thereafter, the suspension was stirred at $70{ }^{\circ} \mathrm{C}$ during $8 \mathrm{~h}$ and dried in an oven at $90{ }^{\circ} \mathrm{C}$. The solids obtained were calcined at $500{ }^{\circ} \mathrm{C}$ during $2 \mathrm{~h}$ in air at $50 \mathrm{~mL} / \mathrm{min}$. Finally, catalysts were macerated and passed through a 100 mesh (ASTM) sieve.

\subsection{Catalyst Characterization}

Specific surface area was determined from adsorption-desorption isotherms of nitrogen at $-196{ }^{\circ} \mathrm{C}$ using an ASAP 2020 apparatus (Micromeritics, Norcross, GA, USA) and applying the BET method. The volume and diameter of porous materials were estimated 
using the Barrett-Joyner-Halenda (BJH) method using the nitrogen desorption branches of the isotherm. Before the analysis, the solids were degasified for $6 \mathrm{~h}$ at $400{ }^{\circ} \mathrm{C}$.

The structural properties of catalysts were characterized by X-ray diffraction (XRD) using a Bruker diffractometer (model D8 with Bragg-Brentano, Billerica, MA, USA) with a $\mathrm{Cu}$ anode $\left(\mathrm{K}_{\alpha 1}=1.540598 \AA\right)$ operated at $40 \mathrm{kV}$ and $40 \mathrm{~mA}$. The diffraction patterns were recorded in the $2 \theta$ range of $5-75^{\circ}$ with a step interval of $0.02^{\circ}$ and a period of $0.2 \mathrm{~s}$.

Scanning electron microscopy (SEM) was used to analyze the morphological properties of the catalysts. For these analyses, a high-resolution VEGA (Shimadzu) instrument was used. Before taking images, the samples were deposited onto a graphite tape and coated with a nanofilm of gold.

Diffuse reflectance infrared with Fourier-transform (DRIFT) spectra were measured on an FT-IR spectrometer (Shimadzu IR Tracer -100, Kyoto, Japan) equipped with a Harrick Praying Mantis accessory and a high-temperature reaction chamber for determining the acidity of catalysts. The samples were initially pretreated in the chamber at $400{ }^{\circ} \mathrm{C}$ under nitrogen $(30 \mathrm{~mL} / \mathrm{min})$ for $1 \mathrm{~h}$. Then, the chamber was cooled to room temperature and saturated with $\mathrm{NH}_{3}(30 \mathrm{~mL} / \mathrm{min})$ for $15 \mathrm{~min}$. Finally, the desorption process was carried out to different temperatures $\left(25,100,200,300\right.$, and $\left.450{ }^{\circ} \mathrm{C}\right)$. Thus, the IR spectra were acquired at the end of each stage of ammonia adsorption and in each stage of temperature. All spectra were recorded with a resolution of $4 \mathrm{~cm}^{-1}$ in the range of wavenumber of 400 to $4000 \mathrm{~cm}^{-1}$ and converted using the Kubelka-Munk function.

\subsection{Reaction Conditions}

Reactions were carried out under autogenous pressure in a Parr reactor (PARR, model 4590, Moline, IL, USA) of $100 \mathrm{~mL}$ equipped with a mechanical stirrer and temperature control. The temperatures evaluated were 250,300 , and $350{ }^{\circ} \mathrm{C}$ during $0.5 \mathrm{~h}$ under $600 \mathrm{rpm}$. Then, $40 \mathrm{~g}$ of PFAD were placed in the reactor, and catalyst mass was $5 \mathrm{wt} \%$ related to the mass of substrate.

At the end of the reaction, the liquid products were filtered, and the OLPs and solid waste yields were calculated using the Equation (1) as follows:

$$
\mathrm{Y}(\%)=\frac{m_{\text {fraction } \mathrm{i}}}{m_{\text {initial }}} \times 100 \%
$$

where $m_{\text {fraction } \mathrm{i}}$ is the mass of liquid organic products or mass of solid waste and $m_{\text {initial }}$ is the initial mass of substrate (PFAD). The yield to gaseous products was calculated by mass difference. The OLPs fractions obtained were distillated, and the products were identified and quantified by gas chromatography. Finally, the catalyst was recovered by washing with organic solvent (hexane). The Figure 11 shows a scheme of separation of products and the catalyst after reaction. 


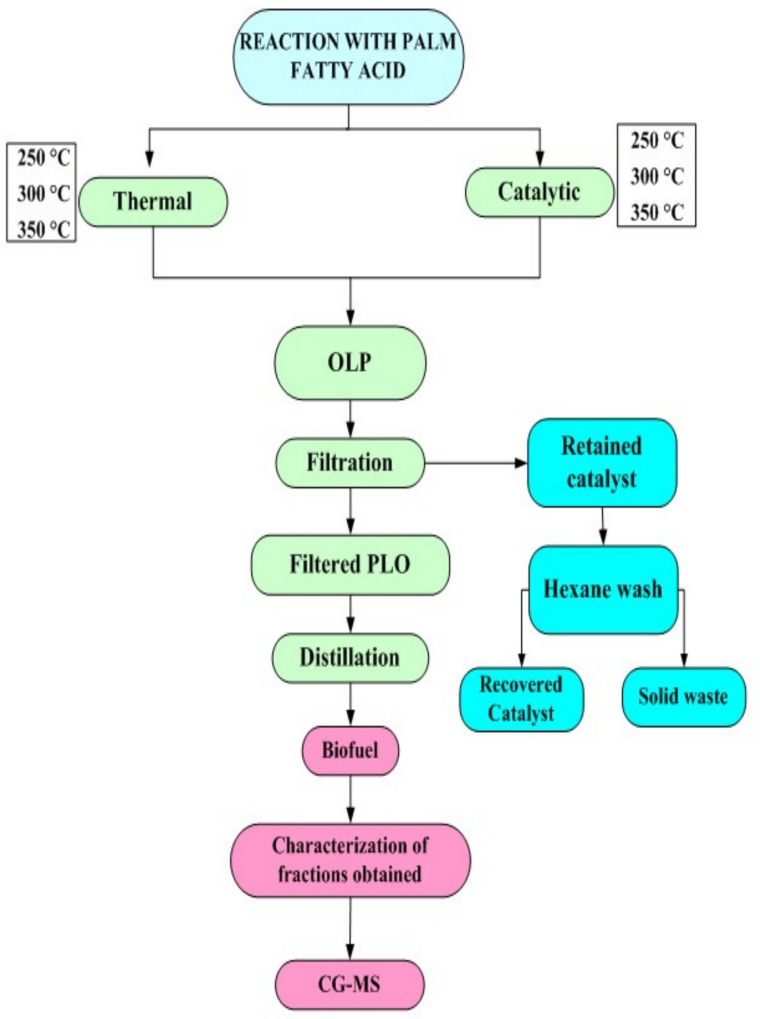

Figure 11. Scheme of separation of products and catalyst.

\subsection{Identification and Quantification of PFAD and Reaction Products}

Palm fatty acid distillate was analyzed by gas chromatography using a Thermo trace GC-ultra chromatograph, equipped with a flame ionization detector (FID) and CP-Sil 5 CB column $(30 \mathrm{~m} \times 0.53 \mathrm{~mm} \times 1.5 \mu \mathrm{m})$. Before identification, the sample was esterified and compared with the respective standard of methyl-esters. All the peaks were normalized by the total area of the chromatogram.

Identification and quantification of reaction products were performed using a gas chromatograph coupled to a mass spectrometer detector (Shimadzu GC-MS-2010 with interface QP2010 and electron impact, Kyoto, Japan) equipped with a DB-5 (30 m $\times 0.25$ $\mathrm{mm} \times 0.25 \mu \mathrm{m})$ capillary column.

Yield to hydrocarbons in DO reactions was evaluated using Equation (2):

$$
\text { Yield to hydrocarbons }=\frac{\Sigma n_{0}+\Sigma n_{i}}{\Sigma n_{z}} \times 100
$$

where: $n_{0}=$ Areaofalkenes; $n_{i}=$ Areaofalkanes; $n_{Z}=$ Areaoftotalproducts.

The hydrocarbon selectivity (S) was calculated using the Equation (3):

$$
\mathrm{S}=\frac{C_{x}}{\sum n_{i}} \times 100
$$

where, $C_{x}=$ Areaofdesiredhydrocarbonsfraction and $n_{i}=$ Areaoftotalhydrocarbons.

\section{Conclusions}

A systematic procedure was made to evaluate the catalytic activity of $\mathrm{Ni}, \mathrm{Co}$, and $\mathrm{Ni}$-Co supported catalysts in the deoxygenation reactions of palm fatty acid distillate (PFAD) to produce hydrocarbons under solventless and hydrogen-absence conditions. The NiZeo catalyst evaluated to $350{ }^{\circ} \mathrm{C}$ during $0.5 \mathrm{~h}$ showed the best yield to hydrocarbons production in the range of $\mathrm{C}_{15}-\mathrm{C}_{17}$ as the main product followed by an important fraction in the range of $\mathrm{C}_{11}-\mathrm{C}_{14}$, which indicates the production of biofuel in the range of diesel. 
However, it is important to note that the incorporation of cobalt in the catalyst (NiCoZeo) showed similar results for the yield of hydrocarbon and selectivity to $C_{15}-C_{17}$ and $C_{11}-C_{14}$, but at $300{ }^{\circ} \mathrm{C}$, indicating the cooperative effect between $\mathrm{Ni}$ and $\mathrm{Co}$ in the catalyst.

On the other hand, a low proportion of cracking products were obtained due to the low acidity of the synthesized zeolitic material composed of a mixture of zeolite A and sodalite. However, it is relevant to mention that these results were obtained at a low scale and it will be key to verify them at an industrial scale. It will be necessary to carry out a careful study on the effect of impurities in the substrate on the activity and stability of catalysts through several reaction cycles.

Finally, this work is a contribution to the investigations related to the production of renewable fuels obtained from agroindustrial wastes and using low-cost supported catalysts.

\begin{abstract}
Author Contributions: B.F.H.d.O.: Conceptualization, methodology, validation, formal analysis, investigation, review and editing, writing —original draft preparation, visualization. L.F.d.F.: Conceptualization, writing - review and editing, supervision, funding acquisition. N.C.F.C.: Conceptualization, methodology, validation, formal analysis, investigation. N.F.d.P.R.: Conceptualization, writingreview and editing, supervision, funding acquisition, project administration. M.V.: Conceptualization, methodology, validation, formal analysis, investigation, review and editing, writing-original draft preparation, visualization, writing-original draft preparation, supervision. All authors have read and agreed to the published version of the manuscript.
\end{abstract}

Funding: This research was funded by VALE S. A. and Brazilian sponsoring agencies CNPQ, CAPES, FINEP, and FAPESPA, and the APC was funded by PROPESP/UFPA.

Acknowledgments: The authors acknowledge LEVAP, LABNANO-AMAZON/UFPA network. PROPESP/UFPA. This work has been mainly supported by Vale Project 3390 (VALE S. A.) and Brazilian sponsoring agencies CNPQ, CAPES, FINEP, and FAPESPA. The authors also acknowledge to research group Estado Sólido y Catálisis Ambiental (ESCA) of the Universidad Nacional de Colombia, sede Bogotá for the financing of this work.

Conflicts of Interest: The authors declare no conflict of interest.

\title{
References
}

1. Kamaruzaman, M.F.; Taufiq-Yap, Y.H.; Derawi, D. Green diesel production from palm fatty acid distillate over SBA-15-supported nickel, cobalt, and nickel/cobalt catalysts. Biomass Bioenergy 2020, 134, 105476. [CrossRef]

2. Pattanaik, B.P.; Misra, R.D. Effect of reaction pathway and operating parameters on the deoxygenation of vegetable oils to produce diesel range hydrocarbon fuels: A review. Renew. Sustain. Energy Rev. 2017, 73, 545-557. [CrossRef]

3. Baharudin, K.B.; Taufiq-Yap, Y.H.; Hunns, J.; Isaacs, M.; Wilson, K.; Derawi, D. Mesoporous NiO/Al-SBA-15 catalysts for solvent-free deoxygenation of palm fatty acid distillate. Microporous Mesoporous Mater. 2019, 276, 13-22. [CrossRef]

4. Mâncio, A.A.; da Costa, K.M.B.; Ferreira, C.C.; Santos, M.C.; Lhamas, D.E.L.; da Mota, S.A.P.; Leão, R.A.C.; de Souza, R.O.M.A.; Araújo, M.E.; Borges, L.E.P.; et al. Process analysis of physicochemical properties and chemical composition of organic liquid products obtained by thermochemical conversion of palm oil. J. Anal. Appl. Pyrolysis 2017, 123, 284-295. [CrossRef]

5. Mba, O.I.; Dumont, M.J.; Ngadi, M. Palm oil: Processing, characterization and utilization in the food industry-A review. Food Biosci. 2015, 10, 26-41. [CrossRef]

6. Hachemi, I.; Kumar, N.; Mäki-Arvela, P.; Roine, J.; Peurla, M.; Hemming, J.; Salonen, J.; Murzin, D.Y. Sulfur-free Ni catalyst for production of green diesel by hydrodeoxygenation. J. Catal. 2017, 347, 205-221. [CrossRef]

7. Baharudin, K.B.; Abdullah, N.; Taufiq-Yap, Y.H.; Derawi, D. Renewable diesel via solventless and hydrogen-free catalytic deoxygenation of palm fatty acid distillate. J. Clean. Prod. 2020, 274, 122850. [CrossRef]

8. Xu, H.; Lee, U.; Wang, M. Life-cycle energy use and greenhouse gas emissions of palm fatty acid distillate derived renewable diesel. Renew. Sustain. Energy Rev. 2020, 134, 110144. [CrossRef]

9. Boonrod, B.; Prapainainar, C.; Narataruksa, P.; Kantama, A.; Saibautrong, W.; Sudsakorn, K.; Mungcharoen, T.; Prapainainar, P. Evaluating the environmental impacts of bio-hydrogenated diesel production from palm oil and fatty acid methyl ester through life cycle assessment. J. Clean. Prod. 2017, 142, 1210-1221. [CrossRef]

10. Abdulkareem-Alsultan, G.; Asikin-Mijan, N.; Mustafa-Alsultan, G.; Lee, H.V.; Wilson, K.; Taufiq-Yap, Y.H. Efficient deoxygenation of waste cooking oil over $\mathrm{Co}_{3} \mathrm{O}_{4}-\mathrm{La}_{2} \mathrm{O}_{3}$-doped activated carbon for the production of diesel-like fuel. RSC Adv. 2020, 10, 4996-5009. [CrossRef]

11. Asikin-Mijan, N.; Lee, H.V.; Abdulkareem-Alsultan, G.; Afandi, A.; Taufiq-Yap, Y.H. Production of green diesel via cleaner catalytic deoxygenation of Jatropha curcas oil. J. Clean. Prod. 2017, 167, 1048-1059. [CrossRef] 
12. Kordulis, C.; Bourikas, K.; Gousi, M.; Kordouli, E.; Lycourghiotis, A. Development of Nickel Based Catalysts for the Transformation of Natural Triglycerides and Related Compounds into Green Diesel: A Critical Review; Elsevier: Amsterdam, The Netherlands, 2016; Volume 181.

13. Asikin-Mijan, N.; Lee, H.V.; Juan, J.C.; Noorsaadah, A.R.; Abdulkareem-Alsultan, G.; Arumugam, M.; Taufiq-Yap, Y.H. Waste clamshell-derived $\mathrm{CaO}$ supported $\mathrm{Co}$ and $\mathrm{W}$ catalysts for renewable fuels production via cracking-deoxygenation of triolein. J. Anal. Appl. Pyrolysis 2016, 120, 110-120. [CrossRef]

14. Zulkepli, S.; Juan, J.C.; Lee, H.V.; Rahman, N.S.A.; Show, P.L.; Ng, E.P. Modified mesoporous HMS supported Ni for deoxygenation of triolein into hydrocarbon-biofuel production. Energy Convers. Manag. 2018, 165, 495-508. [CrossRef]

15. Wako, F.M.; Reshad, A.S.; Bhalerao, M.S.; Goud, V.V. Catalytic cracking of waste cooking oil for biofuel production using zirconium oxide catalyst. Ind. Crops Prod. 2018, 118, 282-289. [CrossRef]

16. Yigezu, Z.D.; Muthukumar, K. Catalytic cracking of vegetable oil with metal oxides for biofuel production. Energy Convers. Manag. 2014, 84, 326-333. [CrossRef]

17. Yoosuk, B.; Sanggam, P.; Wiengket, S.; Prasassarakich, P. Hydrodeoxygenation of oleic acid and palmitic acid to hydrocarbon-like biofuel over unsupported Ni-Mo and Co-Mo sulfide catalysts. Renew. Energy 2019, 139, 1391-1399. [CrossRef]

18. Romero, M.J.A.; Pizzi, A.; Toscano, G.; Busca, G.; Bosio, B.; Arato, E. Deoxygenation of waste cooking oil and non-edible oil for the production of liquid hydrocarbon biofuels. Waste Manag. 2016, 47, 62-68. [CrossRef]

19. Kikhtyanin, O.V.; Rubanov, A.E.; Ayupov, A.B.; Echevsky, G.V. Hydroconversion of sunflower oil on Pd/SAPO-31 catalyst. Fuel 2010, 89, 3085-3092. [CrossRef]

20. Ahmed, A.H. Recent Studies on the Catalytic Action of Transition Metal Oxides and Complexes. J. Appl. Sci. Res. 2010, $6,1142-1157$.

21. Lu, Q.; Zhang, Z.F.; Dong, C.Q.; Zhu, X.F. Catalytic upgrading of biomass fast pyrolysis vapors with nano metal oxides: An analytical Py-GC/MS study. Energies 2010, 3, 1805. [CrossRef]

22. Kaewmeesri, R.; Nonkumwong, J.; Kiatkittipong, W.; Laosiripojana, N.; Faungnawakij, K. Deoxygenations of palm oil-derived methyl esters over mono- And bimetallic NiCo catalysts. J. Environ. Chem. Eng. 2021, 9, 105128. [CrossRef]

23. Zhang, Q.; Wang, T.; Xu, Y.; Zhang, Q.; Ma, L. Production of liquid alkanes by controlling reactivity of sorbitol hydrogenation with a Ni/HZSM-5 catalyst in water. Energy Convers. Manag. 2014, 77, 262-268. [CrossRef]

24. Choo, M.Y.; Oi, L.E.; Ling, T.C.; Ng, E.P.; Lin, Y.C.; Centi, G.; Juan, J.C. Deoxygenation of triolein to green diesel in the H2-free condition: Effect of transition metal oxide supported on zeolite Y. J. Anal. Appl. Pyrolysis 2020, 147, 104797. [CrossRef]

25. Cao, X.; Li, L.; Shitao, Y.; Liu, S.; Hailong, Y.; Qiong, W.; Ragauskas, A.J. Catalytic conversion of waste cooking oils for the production of liquid hydrocarbon biofuels using in-situ coating metal oxide on SBA-15 as heterogeneous catalyst. J. Anal. Appl. Pyrolysis 2019, 138, 137-144. [CrossRef]

26. Maia, A.Á.B.; Dias, R.N.; Angélica, R.S.; Neves, R.F. Influence of an aging step on the synthesis of zeolite NaA from Brazilian Amazon kaolin waste. J. Mater. Res. Technol. 2019, 8, 2924-2929. [CrossRef]

27. Ayele, L.; Pérez-Pariente, J.; Chebude, Y.; Díaz, I. Synthesis of zeolite A from Ethiopian kaolin. Microporous Mesoporous Mater. 2015, 215, 29-36. [CrossRef]

28. Cruz, T.J.T.; Melo, M.I.S.; Pergher, S. Optimization of parameters and methodology for the synthesis of LTA-type zeolite using light coal ash. Appl. Sci. 2020, 10, 7332. [CrossRef]

29. Wang, J.Q.; Huang, Y.X.; Pan, Y.; Mi, J.X. Hydrothermal synthesis of high purity zeolite A from natural kaolin without calcination. Microporous Mesoporous Mater. 2014, 199, 50-56. [CrossRef]

30. Cortés, J.C.; Muñoz, M.; Macías, L.; Molina, R.; Moreno, S. Incorporation of Ni and Mo on delaminated clay by auto-combustion and impregnation for obtaining decane hydroconversion catalysts. Catal. Today 2017, 296, 205-213. [CrossRef]

31. Namchot, W.; Jitkarnka, S. Impacts of nickel supported on different zeolites on waste tire-derived oil and formation of some petrochemicals. J. Anal. Appl. Pyrolysis 2016, 118, 86-97. [CrossRef]

32. Chareonpanich, M.; Jullaphan, O.; Tang, C. Bench-scale synthesis of zeolite A from subbituminous coal ashes with high crystalline silica content. J. Clean. Prod. 2011, 19, 58-63. [CrossRef]

33. Thommes, M.; Kaneko, K.; Neimark, A.V.; Olivier, J.P.; Rodriguez-Reinoso, F.; Rouquerol, J.; Sing, K.S.W. Physisorption of gases, with special reference to the evaluation of surface area and pore size distribution (IUPAC Technical Report). Pure Appl. Chem. 2015, 87, 1051-1069. [CrossRef]

34. Ayele, L.; Pérez, E.; Mayoral, Á.; Chebude, Y.; Díaz, I. Synthesis of zeolite A using raw kaolin from Ethiopia and its application in removal of Cr(III) from tannery wastewater. J. Chem. Technol. Biotechnol. 2018, 93, 146-154. [CrossRef]

35. Santana, D.L.; Saraiva, A.C.F.; Neves, R.F.; Silva, D.L. Zeólita A sintetizada a partir de rejeitos do processo de beneficiamento de caulim Zeolite A synthesized from wastes of kaolin improvement process. Cerâmica 2012, 58, 238-243. [CrossRef]

36. Liu, J.; Li, X.; Zhao, Q.; Ke, J.; Xiao, H.; Lv, X.; Liu, S.; Tadé, M.; Wang, S. Mechanistic investigation of the enhanced NH3-SCR on cobalt-decorated Ce-Ti mixed oxide: In situ FTIR analysis for structure-activity correlation. Appl. Catal. B Environ. 2017, 200, 297-308. [CrossRef]

37. Torres-Luna, J.A.; Moreno, S.; Molina, R.; Carriazo, J.G. Hydroconversion of n -Decane over Ni-Mo Supported on Modified Halloysite Catalysts. Energy Fuels 2018, 32, 9782-9792. [CrossRef] 
38. Alsultan, G.A.; Asikin-Mijan, N.; Lee, H.V.; Albazzaz, A.S.; Taufiq-Yap, Y.H. Deoxygenation of waste cooking to renewable diesel over walnut shell-derived nanorode activated carbon supported $\mathrm{CaO}-\mathrm{La}_{2} \mathrm{O}_{3}$ catalyst. Energy Convers. Manag. 2017, 151, 311-323. [CrossRef]

39. Asikin-Mijan, N.; Lee, H.V.; Marliza, T.S.; Taufiq-Yap, Y.H. Pyrolytic-deoxygenation of triglycerides model compound and non-edible oil to hydrocarbons over $\mathrm{SiO}_{2}-\mathrm{Al}_{2} \mathrm{O}_{3}$ supported $\mathrm{NiO}-\mathrm{CaO}$ catalysts. J. Anal. Appl. Pyrolysis 2018, 129, $221-230$. [CrossRef]

40. Santos, M.C.; Lourenço, R.M.; de Abreu, D.H.; Pereira, A.M.; de Castro, D.A.R.; Pereira, M.S.; Almeida, H.S.; Mâncio, A.A.; Lhamas, D.E.L.; da Mota, S.A.P.; et al. Gasoline-like hydrocarbons by catalytic cracking of soap phase residue of neutralization process of palm oil (Elaeis guineensis Jacq). J. Taiwan Inst. Chem. Eng. 2017, 71, 106-119. [CrossRef]

41. Li, T.; Cheng, J.; Huang, R.; Yang, W.; Zhou, J.; Cen, K. Hydrocracking of palm oil to jet biofuel over different zeolites. Int. J. Hydrogen Energy 2016, 41, 21883-21887. [CrossRef]

42. Peng, B.; Yao, Y.; Zhao, C.; Lercher, J.A. Towards quantitative conversion of microalgae oil to diesel-range alkanes with bifunctional catalysts. Angew. Chem. Int. Ed. 2012, 51, 2072-2075. [CrossRef] [PubMed]

43. Safa Gamal, M.; Asikin-Mijan, N.; Arumugam, M.; Rashid, U.; Taufiq-Yap, Y.H. Solvent-free catalytic deoxygenation of palm fatty acid distillate over cobalt and manganese supported on activated carbon originating from waste coconut shell. J. Anal. Appl. Pyrolysis 2019, 144, 104690. [CrossRef]

44. Gamal, M.S.; Asikin-Mijan, N.; Khalit, W.N.A.W.; Arumugam, M.; Izham, S.M.; Taufiq-Yap, Y.H. Effective catalytic deoxygenation of palm fatty acid distillate for green diesel production under hydrogen-free atmosphere over bimetallic catalyst CoMo supported on activated carbon. Fuel Process. Technol. 2020, 208, 106519. [CrossRef]

45. Gosselink, R.W.; Hollak, S.A.W.; Chang, S.W.; Van Haveren, J.; De Jong, K.P.; Bitter, J.H.; Van Es, D.S. Reaction pathways for the deoxygenation of vegetable oils and related model compounds. ChemSusChem 2013, 6, 1576-1594. [CrossRef] [PubMed]

46. Da Silva Filho, S.H.; Bieseki, L.; Da Silva, A.R.; Maia, A.A.B.; Gil, R.A.S.S.; Pergher, S.B.C. Synthesis of Zeolite A employing Amazon kaolin waste. Ceramica 2015, 61, 409-413. [CrossRef]

47. Maia, A.A.B.; Angélica, R.S.; Neves, R.F. Estabilidade térmica da zeólita A sintetizada a partir de um rejeito de caulim da Amazônia. Cerâmica 2008, 54, 345-350. [CrossRef] 